\title{
Data report: carbon isotope compositions of methane in void gas samples from IODP Expedition 315 Site C0001, Nankai Trough, offshore Japan'
}

\author{
Hiroyuki Saito, ${ }^{2,3}$ Noriyuki Suzuki, ${ }^{2}$ and Urumu Tsunogai ${ }^{2,4}$
}

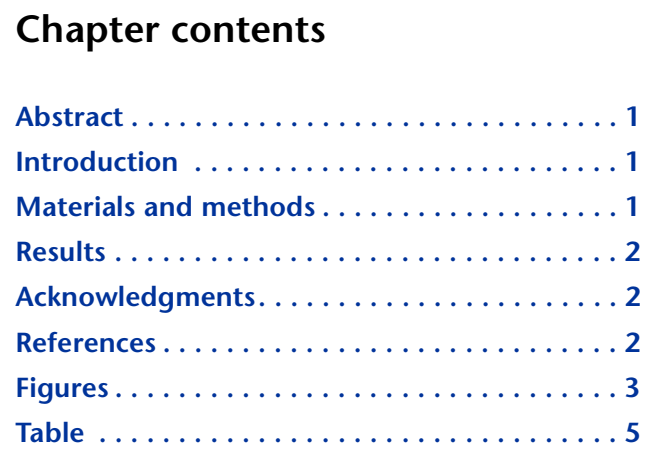

${ }^{1}$ Saito, H., Suzuki, N., and Tsunogai, U., 2013. Data report: carbon isotope compositions of methane in void gas samples from IODP Expedition 315 Site C0001, Nankai Trough, offshore Japan. In Kinoshita, M., Tobin, H., Ashi, J., Kimura, G., Lallemant, S., Screaton, E.J., Curewitz, D., Masago, H., Moe, K.T., and the Expedition 314/315/316 Scientists, Proc. IODP, 314/315/316: Washington, DC (Integrated Ocean Drilling Program Management International, Inc.). doi:10.2204/iodp.proc.314315316.209.2013 2Department of Natural History Sciences, Faculty of Science, Hokkaido University, N10W8 Kita-ku, Sapporo 060-0810, Japan.

${ }^{3}$ Present address: Research Division of JAPEX Earth Energy Frontier, Creative Research Institution, Hokkaido University, N21W10 Kita-ku, Sapporo 001-0021, Japan. hsaito@cris.hokudai.ac.jp ${ }^{4}$ Present address: Graduate School of Environmental Studies, Nagoya University, Furocho, Chikusa-ku, Nagoya 464-8601, Japan.

\begin{abstract}
We investigated carbon isotope compositions of methane and molecular compositions in void gas samples from Integrated Ocean Drilling Program Expedition 315 Site C0001. Methane is the predominant gas with traces of ethane and no heavier hydrocarbons detected. The methane/ethane $\left(\mathrm{C}_{1} / \mathrm{C}_{2}\right)$ ratios of all samples are higher than 5500 . The $\delta^{13} \mathrm{C}$ values of methane range from $-74.9 \%$ to $-73.9 \%$. These data indicate that methane found in Hole C0001F is predominantly of microbial origin.
\end{abstract}

\section{Introduction}

Nankai Trough is one of the most extensively studied subduction zones in the world and is known as an area of active subsurface fluid circulation. The widely observed bottom-simulating reflectors suggest the presence of gas hydrates (Matsumoto et al., 2004). Many fractures and faults developed within the accretionary prism are most likely providing conduits of nutrient and energy substrates that potentially support indigenous microbial population and activities in the subsurface environment (Saito and Suzuki, 2007). Methane production derived from gas hydrate dissociation and migration of thermogenic gas from deeper depths are also expected. The carbon isotope compositions of methane in combination with gas molecular compositions have been widely used for the characterization of hydrocarbon gas origin (Bernard et al., 1977; Rice and Claypool, 1981). In this study, we measured the carbon isotope compositions of methane and molecular compositions in void gas samples from Site C0001, which will provide critical clues to the origin and migration paths of the hydrocarbon gas in this area.

\section{Materials and methods}

Six void gas samples were taken from 156 to 240 meters below seafloor (mbsf) in Hole C0001F. The sections for sampling void gas were restricted because the release of void gas from the core liner was preferred in order to avoid explosion caused by gas expansion. Void gas samples were collected directly through the core liner with a plastic syringe and were transferred into $65 \mathrm{~mL}$ vials that were vacuumed beforehand, sealed with rubber stoppers, and crimp-sealed with aluminum caps. Void gas samples 
were analyzed for volatile hydrocarbon contents on board following the method of Pimmel and Claypool (2001). After analyzing the samples, they were preserved at $4^{\circ} \mathrm{C}$ for later measurement in the onshore laboratory at Hokkaido University, Japan.

In the shore laboratory, concentrations and carbon isotope compositions of methane in void gas samples were measured by gas chromatograph/combustion/isotope ratio mass spectrometer (HP6850GC/ Finnigan MAT 252) with the original purge-and-trap system following the method of Hirota et al. (2010). The analytical precision in the determination of the $\delta^{13} \mathrm{C}\left(\left[\left\{\left({ }^{13} \mathrm{C} /{ }^{12} \mathrm{C}_{\text {sample }}\right) /\left({ }^{13} \mathrm{C} /{ }^{12} \mathrm{C}_{\mathrm{PDB}}\right)\right\}-1\right] \times 1000\right)$ of methane through a single analysis is estimated to be better than $0.07 \%$ when more than $5.5 \mathrm{nM}$ of methane is introduced.

In the onshore laboratory, we also measured concentration and carbon isotope compositions of methane in headspace gas samples, but these samples were apparently affected by leakage of methane from sample vials or microbial oxidation of methane in the sample and are not discussed further.

\section{Results}

Concentrations and carbon isotope compositions of methane and methane/ethane $\left(\mathrm{C}_{1} / \mathrm{C}_{2}\right)$ ratios in the void gas samples measured on board and onshore together with headspace gas data measured on board are shown in Table T1 and Figure F1 (see also Table T20 in the "Expedition 315 Site C0001" chapter [Expedition 315 Scientists, 2009]) Methane is the predominant hydrocarbon present in all samples. Concentrations of methane in the void gas samples are 1 order of magnitude higher than those of the maximum range in the headspace gas samples. The $\mathrm{C}_{1} / \mathrm{C}_{2}$ ratio is $>1000$ in most samples, suggesting that methane found at Site C0001 is predominantly of microbial origin (Bernard et al., 1977; Rice and Claypool, 1981).

Carbon isotope compositions of methane in void gas samples measured in the onshore laboratory are shown in Table T1 and Figure F1. The $\delta^{13} \mathrm{C}$ values of methane in void gas samples range from $-74.9 \%$ to $-73.9 \%$ with an average of $-74.2 \%$, which is consistent with their microbial origin (Fig. F2) (Schoell, 1980; Whiticar et al., 1986).

\section{Acknowledgments}

This research used samples and data provided by the Integrated Ocean Drilling Program (IODP). This re- search was supported in part by the 21st Century COE program on "Neo-Science of Natural History" at Hokkaido University (Leader: H. Okada) funded by the Ministry of Education, Culture, Sports, Science, and Technology (MEXT) of Japan.

\section{References}

Bernard, B.B., Brooks, J.M., and Sackett, W.M., 1977. A geochemical model for the characterization of hydrocarbon gas sources in marine sediments. Proc. Offshore Technol. Conf., 2934:435-438.

Expedition 315 Scientists, 2009. Expedition 315 Site C0001. In Kinoshita, M., Tobin, H., Ashi, J., Kimura, G., Lallemant, S., Screaton, E.J., Curewitz, D., Masago, H., Moe, K.T., and the Expedition 314/315/316 Scientists, Proc. IODP, 314/315/316: Washington, DC (Integrated Ocean Drilling Program Management International, Inc.). doi:10.2204/iodp.proc.314315316.123.2009

Hirota, A., Tsunogai, U., Komatsu, D.D., and Nakagawa, F., 2010. Simultaneous determination of $\delta^{15} \mathrm{~N}$ and $\delta^{18} \mathrm{O}$ of $\mathrm{N}_{2} \mathrm{O}$ and $\delta^{13} \mathrm{C}$ of $\mathrm{CH}_{4}$ in nanomolar quantities from a single water sample. Rapid Commun. Mass Spectrom., 24(7):1085-1092. doi:10.1002/rcm.4483

Matsumoto, R., Tomaru, H., and Lu, H., 2004. Detection and evaluation of gas hydrates in the eastern Nankai Trough by geochemical and geophysical methods. Resour. Geol., 54(1):53-67. doi:10.1111/j.17513928.2004.tb00187.x

Pimmel, A., and Claypool, G., 2001. Introduction to shipboard organic geochemistry on the JOIDES Resolution. ODP Tech. Note, 30. doi:10.2973/odp.tn.30.2001

Rice, D.D., and Claypool, G.E., 1981. Generation, accumulation, and resource potential of biogenic gas. $A A P G$ Bull., 65(1):5-25. doi:10.1306/2F919765-16CE-11D7$8645000102 \mathrm{C} 1865 \mathrm{D}$

Saito, H., and Suzuki, N., 2007. Distributions and sources of hopanes, hopanoic acids and hopanols in Miocene to recent sediments from ODP Leg 190, Nankai Trough. Org. Geochem., 38(10):1715-1728. doi:10.1016/j.orggeochem.2007.05.012

Schoell, M., 1980. The hydrogen and carbon isotopic composition of methane from natural gases of various origins. Geochim. Cosmochim. Acta, 44(5):649-661. doi:10.1016/0016-7037(80)90155-6

Whiticar, M.J., Faber, E., and Schoell, M., 1986. Biogenic methane formation in marine and freshwater environments: $\mathrm{CO}_{2}$ reduction vs. acetate fermentation-isotope evidence. Geochim. Cosmochim. Acta, 50:693-709. doi:10.1016/0016-7037(86)90346-7

Initial receipt: 18 October 2010

Acceptance: 26 February 2013

Publication: 2 May 2013

MS 314315316-209 
Figure F1. Plots of methane concentrations and methane/ethane $\left(\mathrm{C}_{1} / \mathrm{C}_{2}\right)$ ratios in headspace gas and void gas samples (onboard analysis) and carbon isotope compositions of methane in void gas samples (onshore analysis), Site C0001. VPDB = Vienna Peedee belemnite.
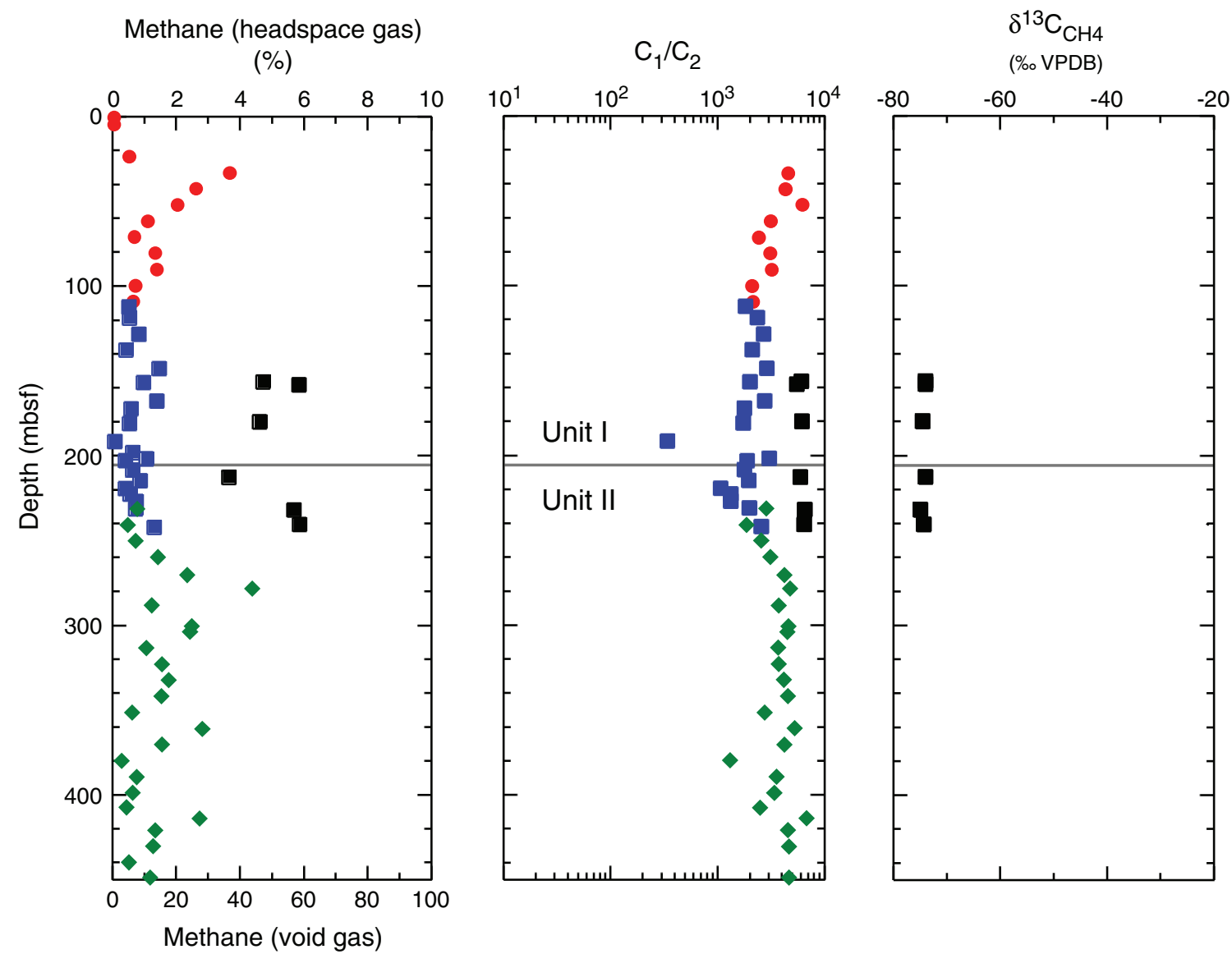

(\%)

Headspace gas:

Hole C0001E

Hole C0001F

Hole $\mathrm{C} 0001 \mathrm{H}$

Void gas:

Hole C0001F 
Figure F2. Plot of $\delta^{13} C_{C H 4}$ vs. methane/ethane $\left(C_{1} / C_{2}\right)$ ratio of void gas samples (Bernard et al., 1977), Site C0001. VPDB $=$ Vienna Peedee belemnite.

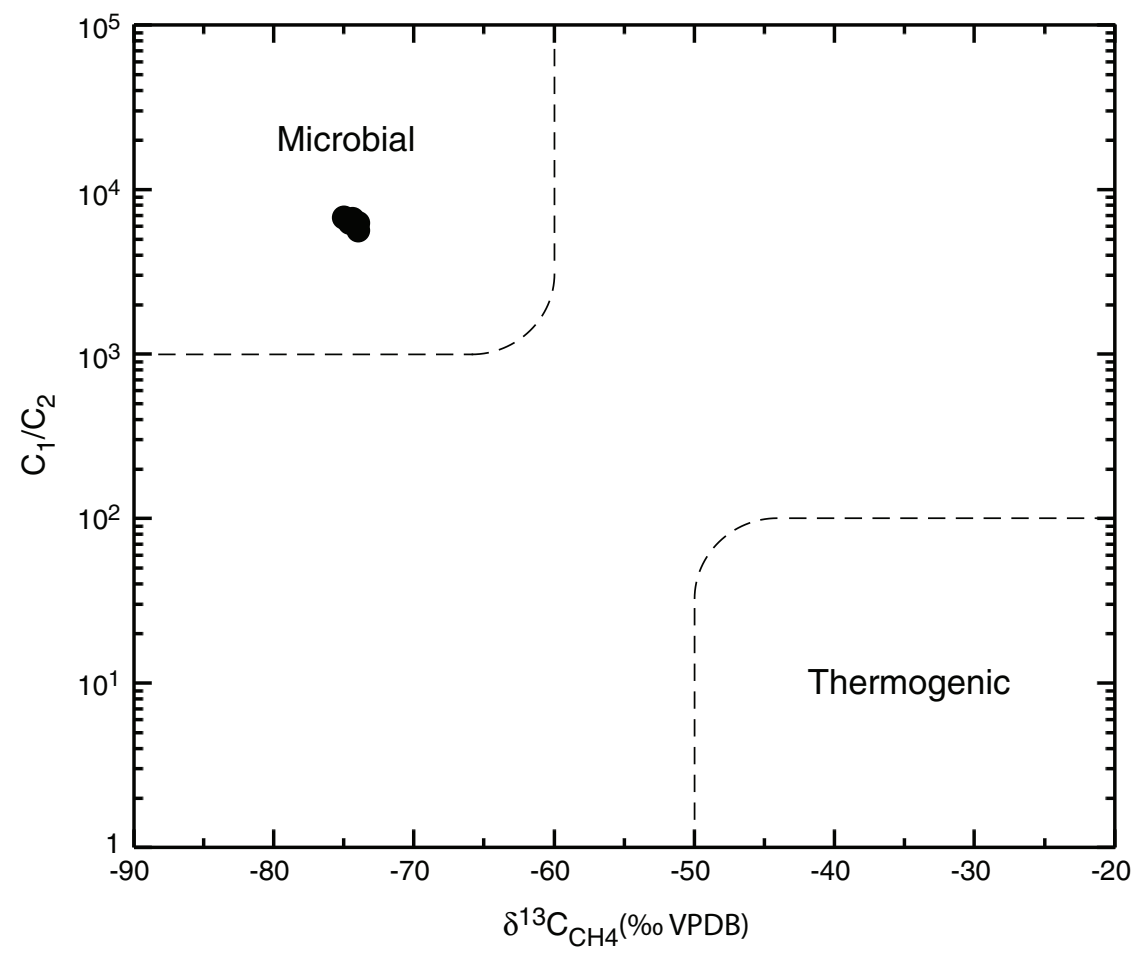


Table T1. Concentrations, carbon isotope compositions, and $\mathrm{C}_{1} / \mathrm{C}_{2}$ ratios in void gas samples, Site $\mathrm{C} 0001$.

\begin{tabular}{lccccc}
\hline & & \multicolumn{2}{c}{ Onboard analysis } & & Onshore analysis \\
\cline { 5 - 5 } $\begin{array}{c}\text { Core, section, } \\
\text { interval }(\mathrm{cm})\end{array}$ & $\begin{array}{c}\text { Depth } \\
(\mathrm{mbsf})\end{array}$ & $\begin{array}{c}\text { Methane } \\
(\%)\end{array}$ & $\mathrm{C}_{1} / \mathrm{C}_{2}$ & & $\begin{array}{c}\delta^{13} \mathrm{C}_{\mathrm{CH} 4} \\
(\% \circ \mathrm{VPDB})\end{array}$ \\
\hline $315-\mathrm{C} 0001 \mathrm{~F}-$ & & & & \\
$6 \mathrm{H}-1,104$ & 156.5 & 47.2 & 6106 & & -73.9 \\
$6 \mathrm{H}-3,26$ & 158.2 & 58.6 & 5549 & & -73.9 \\
$9 \mathrm{H}-1,19$ & 179.9 & 46.1 & 6127 & & -74.5 \\
$14 \mathrm{H}-6,4$ & 212.9 & 36.4 & 5966 & & -74.0 \\
$20 \mathrm{X}-2,78.5$ & 232.0 & 56.8 & 6587 & & -74.9 \\
$21 \mathrm{X}-1,122$ & 240.6 & 58.6 & 6494 & -74.3 \\
\hline
\end{tabular}

VPDB = Vienna Peedee belemnite. 